\title{
FAKTOR YANG MEMPENGARUHI PENGGUNAAN SUSU FORMULA SEBAGAI PENGGANTI ASI EKSKLUSIF
}

\author{
Maftuchah $^{1}$, Anita Indra Afriani ${ }^{2}$, Agustin Maulida $^{3}$ \\ 1,2,3. STIKes Karya Husada Semarang \\ E-mail : maftuchah89@gmail.com
}

\begin{abstract}
ABSTRAK
Kecenderungan para ibu untuk tidak menyusui bayinya secara eksklusif semakin besar. Hal ini dapat dilihat dengan besarnya jumlah ibu menyusui yang memberikan makanan tambahan atau susu formula lebih awal sebagai pengganti ASI. Berbagai alasan dikemukakan oleh ibu-ibu sehingga dalam pemanfaatan ASI secara eksklusif kepada bayinya rendah, antara lain adalah pengaruh iklan/promosi pengganti ASI, ibu bekerja, lingkungan sosial budaya, pendidikan, pengetahuan yang rendah serta dukungan suami yang kurang. Salah satu puskesmas dengan cakupan ASI Eksklusif terendah tahun 2015 yaitu di Puskesmas Tlogosari Wetan Kota Semarang sebesar 55,30 \% . Meskipun mengalami peningkatan di tahun 2016 namun pencapaian ASI Eksklusif di Puskesmas Tlogosari Wetan yaitu $16,4 \%$ belum mencapai target renstra Kota Semarang yaitu $65 \%$. Tehnik sampling yang digunakan adalah total sampling. Uji analisis yang digunakan adalah analisis univariat dan analisis bivariat menggunakan Chi Square. Hasil penelitian menunjukkan bahwa ada hubungan pengetahuan dan pekerjaan dengan penggunaan susu formula sebagai pengganti ASI eksklusif ( $p$ value 0.031 dan 0,015). Sedangkan pendidikan dan peran petugas kesehatan tidak ada hubungan dengan penggunaan susu formula sebagai pengganti ASI eksklusif di Kelurahan Penggaron Kidul-Semarang ( $p$ value 0.303 dan 0.846). Saran bagi masyarakat diharapkan tetap memberikan ASI eksklusif kepada anaknya meskipun ditinggal bekerja.
\end{abstract}

Kata Kunci : Susu Formula; ASI Eksklusif

\section{FACTORS AFFECTING THE USE OF FORMULA MILK AS AN ALTERNATIVE EXCLUSIVE BREASTFEEDING.}

\begin{abstract}
The tendency of mothers who do not breastfeed exclusively the babies are growing. It can be seen by the large number of nursing mothers who provide formula milk as breast milk alternative. The various reasons are put forward by the mothers so that the use of exclusive breast milk is low. These reasons include, the influence of advertisement / breastfeed altenatives, working mother, socio-cultural environment, education, low knowledge, and lack of husband support. One of public health center with the lowest coverage exclusive breastfeeding by $55.30 \%$ in 2015 is Tlogosari Wetan Health Center at Semarang City. Although in 2016 it has been incerased by 16,4\%, however, that number has not fulfilled the strategic plan target of Semarang City as much as $65 \%$. The sampling technique was used Total Sampling. The analysis test was used univariate analysis and Bivariate analysis using ChiSquare. The result showed that there is a relationship between the knowledge and the occupation with the use of formula milk as an alternative for exclusive breastfeeding ( $\mathrm{p}$ value 0.031 and 0.015 ). while education and the role of health practitioner have no relation with the use of formula milk as an alternative for exclusive breastfeeding ( $p$ value 0.303 and 0.846 ). The mothers are expected to continue giving exclusive breastfeeding to the babies even if left to work.
\end{abstract}

Keywords: Formula Milk; Exclusive breastfeeding

Jurnal SMART Kebidanan Sekolah Tinggi Ilmu Kesehatan (STIKes) Karya Husada

Semarang www.stikesyahoedsmg.ac.id/ojs/index.php/sjkb 


\section{Pendahuluan}

World Health Organization (WHO) dan United Nations Childrens Fund (UNICEF) merekomendasikan agar ibu menyusui bayinya saat satu jam pertama setelah melahirkan dan melanjutkan hingga usia 6 bulan pertama kehidupan bayi. Pengenalan makanan pelengkap dengan nutrisi yang memadai dan aman diberikan saat bayi memasuki usia 6 bulan dengan terus menyusui sampai 2 tahun atau lebih (Prasetyono, 2012).

Peraturan Pemerintah (PP) ASI sebagai amanat Undang-Undang Nomor 33 Tahun 2012 tentang kesehatan mengatur tentang pemberian ASI Eksklusif bagi bayi, pembatasan susu formula, termasuk pembatasan pengiklanan produk dan pembentukan ruangan menyusui di perusahaan. Menteri Kesehatan menyebutkan bahwa petugas kesehatan dilarang bekerjasama dengan perusahaan yang memproduksi susu formula. Peraturan Pemerintah (PP) itu akan diatur bahwa susu formula bagi anak berusia dibawah satu tahun tidak boleh diiklankan (UU RI Nomor 33 Tahun 2012 Tentang Kesehatan).

ASI merupakan makanan pertama, utama, dan terbaik bagi bayi, yang bersifat alamiah. ASI mengandung berbagai zat gizi yang dibutuhkan dalam proses pertumbuhan dan perkembangan bayi. Terkait itu, ada suatu hal yang perlu disayangkan, yakni rendahnya pemahaman ibu, keluarga, dan masyarakat mengenai pentingnya ASI bagi bayi. Akibatnya, program pemberian ASI Eksklusif tidak berlangsung secara optimal (Prasetyono, 2012).

Gencarnya kampanye produsen susu formula yang dilakukan para distributor sangat mempengaruhi pemikiran para ibu yang kurang memiliki pengetahuan yang luas tentang ASI. Berdasarkan iklan susu formula yang ada, terjadi sebuah kekeliruan konsep yakni susu formula itu diperlukan oleh ibu yang persediaan air susunya tidak mencukupi kebutuhan anak, sehingga dibutuhkan susu tambahan yang diproduksi oleh perusahaan susu (Prasetyono, 2012).

Kecenderungan para ibu untuk tidak menyusui bayinya secara eksklusif semakin besar. Hal ini dapat dilihat dengan besarnya jumlah ibu menyusui yang memberikan makanan tambahan lebih awal sebagai pengganti ASI. Berbagai alasan dikemukakan oleh ibu-ibu sehingga dalam pemanfaatan ASI secara eksklusif kepada bayinya rendah, antara lain adalah pengaruh iklan/promosi pengganti ASI, ibu bekerja, lingkungan sosial budaya, pendidikan, pengetahuan yang rendah serta dukungan suami yang kurang (Prasetyono, 2012).

Hasil penelitian yang dilakukan oleh UNICEF, mengemukakan bahwa bayi yang diberikan susu formula dibawah usia 6 bulan memiliki kemungkinan meninggal dunia pada bulan pertama kelahirannya dan peluang itu 25 kali lebih tinggi daripada bayi yang disusui 
ibunya secara eksklusif. Pemberian susu formula beresiko meningkatkan terjadinya penyakit infeksi, misalnya infeksi saluran pencernaan (diare) infeksi saluran pernafasan. Selain itu pemberian susu formula yang terlalu dini juga bisa meningkatkan terjadinya penyakit noninfeksi, seperti penyakit alergi, obesitas, hingga kurang gizi.

Provinsi Jawa Tengah cakupan pemberian ASI Eksklusif pada bayi usia 0-6 bulan tahun 2014 sebesar 60,0 \% . Persentase ini menurun di tahun 2015 yaitu hanya sebesar 56,1\% . Data dari Dinas Kesehatan Kota Semarang tahun 2015 menyebutkan bahwa cakupan ASI Eksklusif di kota Semarang yaitu 64,69 \% , pada tahun 2016 ada peningkatan sebesar 3,53\% menjadi 67,16 \% . Data DKK Semarang tahun 2016, cakupan pemberian ASI Eksklusif pada bayi usia 0-6 bulan di Kota Semarang telah mencapai target renstra (65\%) dan bila dibandingkan dengan target nasional masih di bawah target (80\%). Sedangkan bila dibandingkan dengan pencapaian tahun 2015 ada peningkatan dari 64,69\% menjadi 67,16\% pada tahun 2016. Hal ini diduga karena adanya komitmen petugas kesehatan untuk membantu ibu yang mengalami kesulitan dalam menyusui, ada peningkatan pengetahuan ibu tentang manfaat menyusui dan cara menyusui yang tepat serta dukungan dari keluarga, adanya komitmen pengambilan kebijakan dengan keluarnya Peraturan Walikota Semarang (Perwal) No : 7 Tanggal 16 Januari 2013 Tentang Program Peningkatan Pemberian ASI Eksklusif di Kota Semarang (DKK Semarang, 2016).

Salah satu puskesmas dengan cakupan ASI Eksklusif terendah yaitu di Puskesmas Tlogosari Wetan Kota Semarang. Tahun 2014 pencapaian ASI Eksklusif di Puskesmas Tlogosari Wetan sebesar $35 \%$ dan pada tahun 2015 menurun menjadi 33,15\% . Data dari DKK Semarang, pada tahun 2016 cakupan ASI Eksklusif meningkat menjadi 55,30 \% . Meskipun mengalami peningkatan di tahun 2016 namun pencapaian ASI Eksklusif di Puskesmas Tlogosari Wetan yaotu 16,4 \% belum mencapai target renstra Kota Semarang yaitu $65 \%$ (DKK Semarang, 2016) Pencapaian ASI Eksklusif terendah Wilayah kerja Puskesmas Tlogosari Wetan yaitu di Kelurahan Penggaron Kidul (Puskesmas Tlogosari Wetan 2012)

Berdasarkan hasil studi pendahuluan pada bulan Januari 2017 yang dilakukan peneliti di Kelurahan Penggaron Kidul-Semarang, dari 5 ibu yang diwawancarai ada 1 ibu yang memberikan ASI saja pada bayinya yang berusia 6 bulan. Sedangkan 4 ibu lainnya memberikan susu formula. 1 ibu yang memberikan ASI saja kepada bayinya mengatakan bahwa pentingnya pemberian ASI pada bayi hingga usia 6 bulan berharap agar anaknya tumbuh cerdas dan bisa berhemat karena tidak perlu mengeluarkan uang untuk membeli susu 
formula. Dari 4 ibu yang memberikan ASI dan susu formula, 2 diantaranya (bayi berusia 3 bulan) ibu bekerja sebagai buruh pabrik dimana cuti melahirkan hanya mendapat 2 bulan saja. Sehingga saat ibu harus kembali bekerja menyebabkan ibu memberikan susu formula kepada bayinya. Sedangkan 2 ibu lainnya (masing-masing bayi berusia 4 bulan dan 5 bulan) mengatakan bayinya sering rewel dan menangis. Ibu menganggap bayinya kurang kenyang jika diberikan ASI saja, sehingga ibu memberikan tambahan susu formula kepada bayinya.

\section{Tinjauan Teoritis}

\section{ASI Eksklusif}

ASI eksklusif adalah pemberian Air Susu Ibu (ASI) tanpa makanan dan minuman tambahan lain apapun pada bayi berusia 0-6 bulan. Pemberian ASI dalam jumlah cukup dapat memenuhi kebutuhan gizi bayi selama 6 bulan pertama. ASI merupakan makanan alamiah yang pertama dan utama bagi bayi sehingga dapat mencapai tumbuh kembang yang optimal (Walyani, 2015).

\section{Susu Formula}

Susu formula adalah susu bubuk untuk bayi dalam kemasan kotak yang diproduksi oleh sebuah perusahaan susu dan dijual secara bebas di pasaran atau toko-toko (Siti Nur, 2011).

Susu formula boleh diberikan kepada bayi usia 0-6 bulan atas indikasi medi.Kondisi medis bayi yang tidak memungkinkan pemberian ASI Eksklusif menurut PP No.33 tahun 2012 antara lain :

a. Bayi yang hanya dapat menerima susu dengan formula khusus, yaitu bayi dengan kriteria antara lain; bayi dengan galaktosemia klasik, bayi dengan penyakit kemih beraroma sirup maple, bayi dengan fenilketonuria

b. Bayi yang membutuhkan makanan lain selain ASI selama jangka waktu terbatas, yaitu : bayi lahir dengan berat badan kurang dari 1500 gram, bayi lahir kurang dari 32 minggu dari usia kehamilan, bayi baru lahir yang beresiko hipoglikemia

Tabel 1 perbandingan nutrisi yang terkandung pada ASI dan susu formula.

\begin{tabular}{|c|c|c|}
\hline Nutrisi & ASI & Susu formula \\
\hline Lemak & 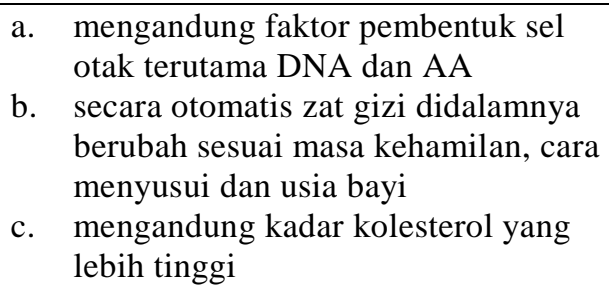 & 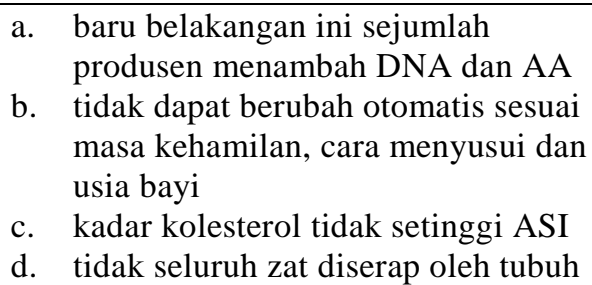 \\
\hline
\end{tabular}




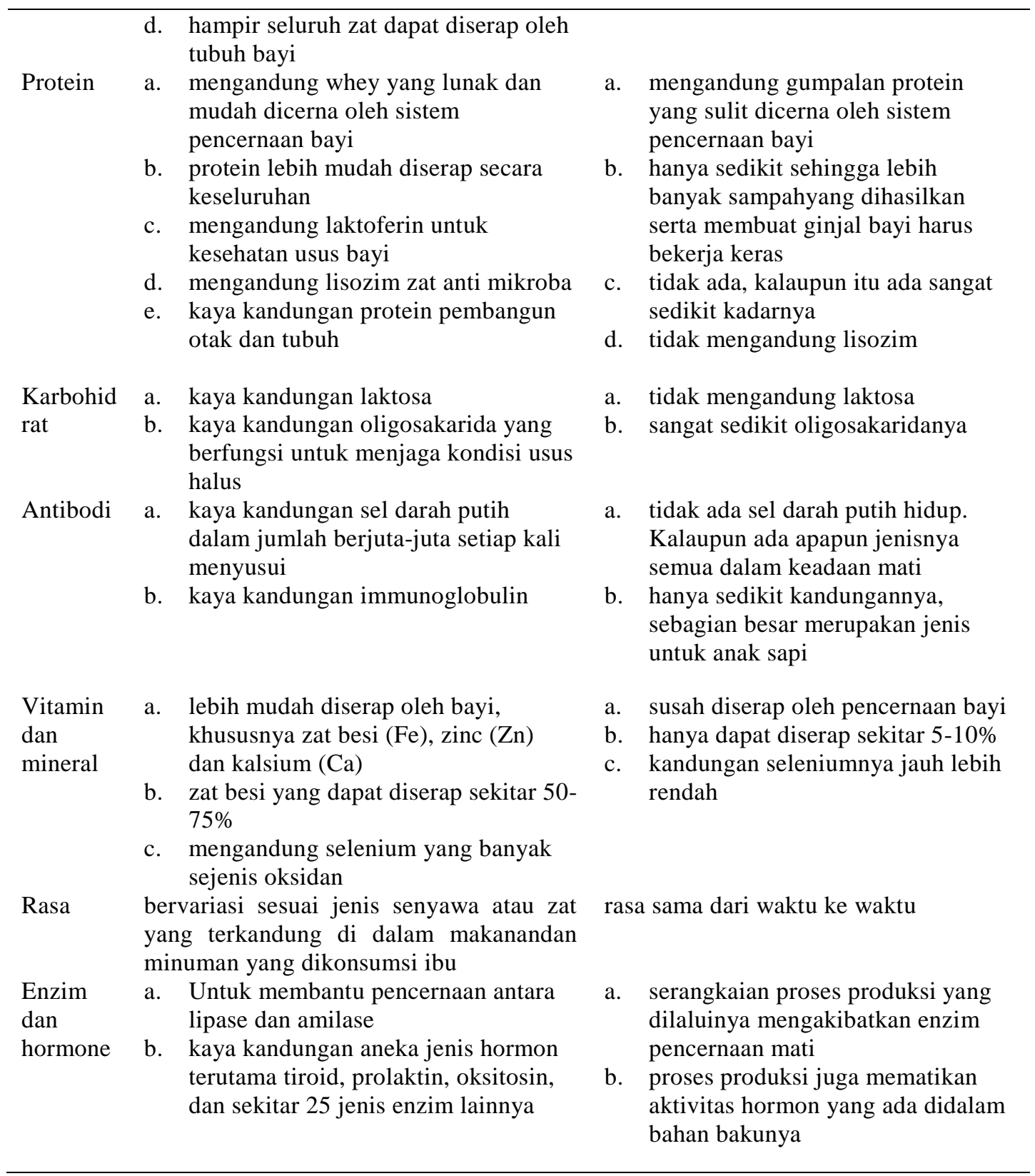

\section{Dampak negatif dalam pemberian susu formula}

Dampak negative yang terjadi pada bayi akibat dari pemberian susu formula,antara lain : Gangguan saluran pencernaan (muntah, diare), Infeksi saluran pernafasan, Meningkatkan resiko serangan asma, Meningkatkan kejadian karies gigi, Menurunkan perkembangan kecerdasan kognitif, meningkatkan resiko obesitas, Meningkatkan resiko penyakit jantung dan pembuluh darah, meningkatkan resiko infeksi yang berasal dari susu formula yang tercemar, meningkatkan kurang gizi, meningkatkan resiko kematian (Prasetyono, 2012). 


\section{Metode Penelitian}

Penelitian ini merupakan penelitian kuantitatif . Penelitian dilaksanakan pada bulan Januari s/d Juli 2017 di Kelurahan Penggaron Kidul-Semarang. Populasi dalam penelitian ini adalah ibu yang memiliki bayi berumur 0-6 bulan sebanyak 36 bayi menggunakan teknik total sampling. Kriteria inklusi : Ibu yang mempunyai bayi berusia 0-6 bulan berdomisili di Kelurahan Penggaron Kidul. Kriteria eksklusi : Bayi dengan kontra indikasi mendapatkan ASI (bayi menderita penyakit galaktosemia, bayi dengan BBLR, ibu bayi yang menderita HIV/AIDS). Instrumen penelitian yang digunakan adalah kuesioner yang sudah dilakukan uji validitas dan reliabilitas. Analisis data dalam penelitian ini menggunakan uji chi square.

\section{Hasil Penelitian}

1. Hubungan Pendidikan Ibu Dengan Praktik Pemberian Susu Formula

Tabel 2. Hubungan Pendidikan Ibu Dengan Praktik Pemberian Susu Formula

\begin{tabular}{|c|c|c|c|c|c|c|c|c|}
\hline \multirow{2}{*}{ Pendidikan $\quad$ Pemberian Sufor } & \multicolumn{2}{|c|}{ Diberi sufor } & \multicolumn{2}{|c|}{ Tdk Sufor } & \multicolumn{2}{|c|}{ Total } & \multirow{2}{*}{$\frac{p \text { value }}{0,303}$} & \multirow{2}{*}{$\frac{O R}{0.228}$} \\
\hline & $\mathrm{N}$ & $\%$ & $\mathrm{n}$ & $\%$ & $\mathrm{~N}$ & $\%$ & & \\
\hline Dasar & 1 & 25 & 3 & 75 & 4 & 100 & & \\
\hline \multirow[t]{2}{*}{ Menengah+Tinggi } & 19 & 59 & 13 & 41 & 32 & 100 & & \\
\hline & 20 & 56 & 16 & 44 & 36 & 100 & & \\
\hline
\end{tabular}

Berdasarkan tabel 2 dapat diketahui bahwa ibu dengan Pendidikan Dasar sebagian besar tidak diberi susu formula (75\%). Sedangkan ibu dengan pendidikan menengah dan tinggi sebagian besar anaknya diberi susu formula (59\%). P value diperoleh 0,303 dengan OR 0.228 .

2. Hubungan Pekerjaan Dengan Praktik Pemberian Susu Formula

Tabel 3. Hubungan Pekerjaan Dengan Praktik Pemberian Susu Formula

\begin{tabular}{|c|c|c|c|c|c|c|c|c|}
\hline \multirow{2}{*}{ Pekerjaan $\quad$ Pemberian Sufor } & \multicolumn{2}{|c|}{ Diberi sufor } & \multicolumn{2}{|c|}{ Tdk Sufor } & \multicolumn{2}{|c|}{ Total } & \multirow{2}{*}{$\frac{p \text { value }}{0,015}$} & \multirow{2}{*}{$\begin{array}{c}O R \\
8.048 \\
\end{array}$} \\
\hline & $\mathrm{n}$ & $\%$ & $\mathrm{n}$ & $\%$ & $\mathrm{~N}$ & $\%$ & & \\
\hline Tidak Bekerja & 13 & 81 & 3 & 19 & 16 & 100 & & \\
\hline Bekerja & 7 & 35 & 13 & 65 & 20 & 100 & & \\
\hline Total & 20 & 56 & 16 & 44 & 36 & 100 & & \\
\hline
\end{tabular}

Berdasarkan tabel 3 dapat diketahui bahwa ibu yang tidak bekerja sebagian besar memberikan susu formula $(81 \%)$. Sedangkan ibu yang bekerja sebagian besar anaknya tidak diberi susu formula (65\%). $P$ value diperoleh 0,015 dengan OR 8.048. 
3. Hubungan Pengetahuan Dengan Praktik Pemberian Susu Formula

Tabel 4. Hubungan Pengetahuan Dengan Praktik Pemberian Susu Formula

\begin{tabular}{lcccccccc}
\hline \multirow{2}{*}{ Pembetahuan } & \multicolumn{7}{c}{ Diberi sufor } & \multicolumn{2}{c}{ Tdk Sufor } & \multicolumn{2}{c}{ Total } & p value & OR \\
\cline { 2 - 10 } Pengerian Sufor & $\mathrm{n}$ & $\%$ & $\mathrm{n}$ & $\%$ & $\mathrm{~N}$ & $\%$ & 0,031 & 0.154 \\
\hline Cukup & 8 & 38 & 13 & 62 & 21 & 100 & & \\
Baik & 12 & 80 & 3 & 20 & 15 & 100 & & \\
\hline Total & 20 & 56 & 16 & 44 & 36 & 10 & & \\
\hline
\end{tabular}

Berdasarkan tabel 4 dapat diketahui bahwa ibu dengan pengetahuan cukup sebagian besar tidak memberikan susu formula pada anaknya (62\%). Sedangkan ibu dengan pengetahuan baik sebagian besar anaknya diberi susu formula (80\%). $P$ value diperoleh 0,031 dengan OR 0.154.

4. Hubungan Peran Petugas Kesehatan dengan Praktk Pemberian Susu Formula

Tabel 5. Hubungan Peran Petugas Kesehatan Dengan Praktik Pemberian Susu Formula

\begin{tabular}{lcccccccc}
\hline \multirow{2}{*}{$\begin{array}{l}\text { Pemberian Sufor } \\
\text { Peran petugas }\end{array}$} & \multicolumn{2}{c}{ Diberi sufor } & \multicolumn{2}{c}{ Tdk Sufor } & \multicolumn{2}{c}{ Total } & p value & OR \\
\cline { 2 - 9 } Kesehatan & $\mathrm{N}$ & $\%$ & $\mathrm{n}$ & $\%$ & $\mathrm{~N}$ & $\%$ & 0,846 & 1.467 \\
\hline Tidak mendukung & 8 & 62 & 5 & 38 & 13 & 100 & \\
Mendukung & 12 & 52 & 11 & 48 & 23 & 100 & & \\
\hline & 20 & 56 & 16 & 44 & 36 & 100 & \\
\hline
\end{tabular}

Berdasarkan tabel 5 dapat diketahui bahwa ibu yang tidak mendapat dukungan dari petugas kesehatan sebagian besar memberikan susu formula pada anaknya (62\%). Sedangkan ibu yang mendapat dukungan dari petugas kesehatan sebagian besar anaknya diberi susu formula (52\%). $P$ value diperoleh 0,846 dengan OR 1.467.

\section{Pembahasan}

1. Pendidikan sebagai faktor yang mempengaruhi Pemberian Susu Formula pada Bayi Usia 0-6 bulan

Hasil penelitian menunjukkan bahwa pendidikan ibu yang mempunyai bayi usia 0-6 bulan sebagian besar pendidikan menengah yaitu SMA. Seseorang yang berpendidikan tinggi dan berpengalaman luas akan lebih bisa menerima alasan untuk tidak memberikan susu formula pada bayinya karena pola pikirnya yang lebih realistis dibandingkan dengan tingkat pendidikan yang rendah.

Ibu-ibu yang berpendidikan dasar namun memilih tidak memberikan susu formula pada bayinya karena dari faktor ibu tidak bekerja sehingga tidak punya penghasilan untuk 
membeli susu formula. Ibu yang tidak bekerja, intensitas untuk bersama bayinya lebih sering sehingga ibu memilih memberikan ASI dibandingkan susu formula. Hasil penelitian diperoleh $P$ value 0,303 artinya tidak ada hubungan antara pendidikan dengan praktik pemberian susu formula pada bayi usia 0-6 bulan.

2. Pekerjaan sebagai faktor yang mempengaruhi Pemberian Susu Formula pada Bayi Usia 0-6 bulan

Pekerjaan merupakan kegiatan seorang ibu dirumah atau diluar rumah dengan maksud mencari nafkah untuk memperoleh pendapatan/penghasilan. Dari hasil penelitian menunjukkan bahwa ibu yang mempunyai bayi usia 0-6 bulan sebagian besar bekerja sebagai wiraswasta. Ibu yang bekerja lebih banyak memberikan susu formula pada bayinya dibandingkan ibu yang tidak bekerja. Seorang ibu yang bekerja diluar rumah intensitas bertemu dengan bayinya sangat minim, sehingga ibu lebih memilih memberikan susu formula pada bayinya. Ibu-ibu yang bekerja dan masih tetap memberikan hanya ASI saja pada bayinya dikarenakan pengetahuan ibu mengenai susu formula baik sehingga ibu memilih memberikan ASI dibandingkan susu formula. Hasil penelitian diperoleh $P$ value 0,015 artinya ada hubungan antara pekerjaan dengan praktik pemberian susu formula pada bayi usia 0-6 bulan.

3. Pengetahuan sebagai faktor yang mempengaruhi Pemberian Susu Formula pada Bayi Usia 0-6 bulan

Berdasarkan pada hasil penelitian diketahui bahwa ibu yang mempunyai bayi usia 06 bulan sebagian besar mempunyai pengetahuan cukup. Dilihat dari hasil kuesioner pengetahuan susu formula, sebagian besar ibu tidak dapat menjawab pertanyaan mengenai susu formula pemula dan susu formula soya. Pengetahuan atau kognitif adalah hal yang sangat penting dalam membentuk tindakan seseorang (Notoadmodjo, 2010). Tindakan untuk memberikan susu formula setelah bayi berumur 6 bulan dilaksanakan berdasarkan pengetahuan yang dimiliki ibu bayi. Ibu yang berpengetahuan baik namun tetap memberikan susu formula karena adanya peran petugas kesehatan yang tidak mendukung ibu dalam pemberian ASI eksklusif. Hasil penelitian diperoleh $P$ value 0,031 artinya ada hubungan antara pengetahuan dengan praktik pemberian susu formula pada bayi usia 0-6 bulan. 
4. Peran Petugas Kesehatan sebagai Faktor yang Mempengaruhu Pemberian Susu Formula pada Bayi Usia 0-6 Bulan

Berdasarkan pada hasil penelitian menunjukkan bahwa ibu yang mempunyai bayi usia 0-6 bulan menyatakan bahwa sebagian besar peran petugas kesehatan mendukung ibu untuk tidak memberikan susu formula pada bayinya. Namun diantara petugas kesehatan yang mendukung, masih ada beberapa peran petugas kesehatan tidak mendukung, dilihat dari hasil kuesioner ibu menyatakan bahwa Bidan tidak menjelaskan manfaat ASI eksklusif bagi bayi maupun bagi ibu. Peran petugas kesehatan yang mendukung pemberian ASI eksklusif maka akan berdampak pada ibu untuk tidak memberikan susu formula pada bayinya. Hasil penelitian diperoleh $P$ value diperoleh 0,846 artinya tidak ada hubungan antara peran petugas kesehatan dengan pemberian susu formula pada bayi usia 0-6 bulan.

\section{Kesimpulan}

Ada hubungan Pekerjaan dan pengetahuan dengan penggunaan susu formula sebagai pengganti ASI eksklusif. Tidak ada hubungan pendidikan dan peran petugas kesehatan dengan penggunaan susu formula sebagai pengganti ASI eksklusif di Kelurahan Penggaron Kidul-Semarang

\section{Saran}

Masyarakat diharapkan tetap memberikan ASI eksklusif kepada anaknya. Untuk dpeneliti selanjutnya iharapkan dapat melakukan penelitian tentang faktor-faktor yang mempengaruhi pemberian susu formula pada bayi usia 0-6 bulan secara kualitatif.

\section{Daftar Pustaka}

A. Wawan dan Dewi M. (2010). Teori dan Pengukuran Pengetahuan Sikap dan Perilaku Manusia Cetakan Kedua. Yogyakarta : NuhaMedika

Abdul Nasir, dkk.(2011). Buku Ajar Metodologi Penelitian Kesehatan Konsep Pembuatan Karya Tulis dan Thesis untuk Mahasiswa Kesehatan. Yogyakarta : Nuha Medika

Apriyanti, Rika. Faktor-Faktor yang Berhubungan dengan Pemberian Susu Formula pada Bayi Umur 0-6 Bulan di BPS Agnes Way Kandis Bandar Lampung. 2013.(tidak dipublikasikan)

Depkes RI. 2016. Profil Kesehatan Indonesia Tahun 2015. Jakarta

Dili Ariwati, Valentina. Hubungan Dukungan Bidan Tentang Pemberian Asi Eksklusif

Jurnal SMART Kebidanan Sekolah Tinggi Ilmu Kesehatan (STIKes) Karya Husada

Semarang www.stikesyahoedsmg.ac.id/ojs/index.php/sjkb 
Dengan Perilaku Pemberian Asi Eksklusif Di Wilayah Kerja Puskesmas Ambarawa Kabupaten Semarang. 2014. (tidak dipublikasikan)

Dinkes Kota Semarang 2016. Profil Kesehatan Kota Semarang Tahun 2015.

Helena, dkk. Faktor yang Mempengaruhi Pemberian Pasi Pada Bayi Usia 0-6 bulan di Wilayah Kerja Puskesmas Christina Martha Tiahahu Kota Ambon.2013. (tidak dipublikasikan)

Indrawati Puspitasari, Ririn. Gambaran Faktor-Faktor Yang Mempengaruhi Pemberian Susu Formula Pada Ibu Yang Mempunyai Bayi Usia 0-6 Bulan di BPA Hj. Renik Suprapti Kelurahan bantarsoka kecamatan Purwokerto Barat Kabupaten Banyumas.2011. (tidak dipublikasikan)

Khamzah, Siti Nur. (2011). Segudang Keajaiban ASI yang Harus Anda Ketahui. Yogyakarta :Flashbook

Khazanah, Nur. (2011). ASI atau Susu Formula Ya? Yogyakarta : Flashbook.

Kodrat, Laksono. (2010). Dahsyatnya ASI dan Laktasi. Yogyakarta : Media Baca.

Nirwana, Ade Benih. (2014). ASI dan Susu Formula Kandungan dan Manfaat ASI dan Susu Formula. Yogyakarta : Nuha Medika

Notoadmodjo, Soekidjo.(2010). Metodologi Penelitian Kesehatan. Jakarta: Rineka Cipta

Nurjannah. Tingkat Pengetahuan Ibu Tentang Resiko Pemberian Susu Formula pada Bayi Umur 0-6 Bulan di Kelurahan Nusukan. 2015 (tidak dipublikasikan)

Ory Okawary, dkk. Hubungan Status Pekerjaan Ibu dengan Pemberian ASI Eksklusif di Wilayah Kerja Puskesmas Seyegan Sleman Yogyakarta. 2015. (tidak dipublikasikan)

Prasetyono, Dwi Sunar. (2012). Buku Pintar Asi Eksklusif Cetakan Kedua. Yogyakarta : Diva Press

Pratiwi, Ayu Nyoman. (2011). Anak Sehat 100 Solusi dr. Tiwi Panduan Lengkap Kesehatan Bayi 0-24 Bulan. Jakarta :Esensi Erlangga Grup.

Puskesmas Tlogosari Wetan. 2016. Laporan Bulanan Bayi dan Balita.

Susanto, Heri. Faktor-Faktor yang Mempengaruhi Pemberian Susu Formula Pada Bayi yang Di Rawat Di Ruang Nifas RSUP Prof. Dr. R. D. Kandou Manado. 2015 (tidak dipublikasikan)

Undang-Undang Republik Indonesia Nomor 33 Tahun 2012 TentangKesehatan

Undang-Undang Republik Indonesia Nomor 36 Tahun 2009 Tentang Kesehatan. 